\title{
POR UMA GEOGRAFIA HUMANA E REGIONAL
}

\author{
CARLOS Alberto MEDEIROS ${ }^{1}$
}

Quando começou a trabalhar em Portugal, na investigação e no ensino, em meados dos anos 60, Suzanne Daveau foi encarada por muitos dos seus colegas, designadamente pelos mais jovens, como uma especialista em geografia física, ou, pelo menos, como uma geógrafa com sensível preferência pelo estudo dos elementos naturais do ambiente.

Ao cabo de pouco tempo, porém, foi fácil verificar o seu interesse pelos problemas humanos e o modo como sobre eles se manifestava com facilidade e pertinência. Mas, no que me diz respeito, foi com alguma surpresa que tomei conhecimento do tema da sua excelente tese de «Doctorat d'Etat»: precisamente um estudo de geografia humana, como vem indicado e expressamente assumido no subtítulo do trabalho sobre Les régions frontalières de la montagne jurassienne $(1959)^{2}$. Ao percorrer com atenção e muito gosto as cinco centenas e meia de páginas que o compõem, desde cedo algumas impressões mais vivas se foram impondo, de tal forma que ainda hoje as recordo perfeitamente. Em primeiro lugar, a clareza com que, logo nos parágrafos iniciais, se enunciam as questões essenciais suscitadas pela investigação; designadamente, através do seguinte passo: «Nous voulons rechercher si la frontière moderne (franco-suisse) qui court à travers la montagne jurassienne a bien, comme l'écrit R. Dion 'une efficacité qui égale et surpasse celle des phénomènes naturels', si la vie des frontaliers est profondément affectée à la fois par la proximité de cette ligne idéale et par l'appartenance à deux communautés politiques différentes, ou bien si, comme le suggère R. Gendarme à propos de la région du Nord, la notion de frontière est aujourd'hui 'dévalorisée', 'les intérêts économiques (ayant) été plus forts que les barrières politiques'» (p. 9-10). Ao longo de todo o livro, estas questões - de tão flagrante pertinência na actualidade, em função da relevância acrescida que tem ganho o problema das fronteiras - são retomadas e discutidas, através dum plano estruturado com coerência e segurança, que contempla exaustivamente o amplo leque de assuntos relacionados com o tema. A autora é guiada por princípios metodológicos sólidos, implicitamente bem inscritos no trabalho - sem necessidade do capítulo prévio

1 Professor Catedrático da Universidade de Lisboa. Investigador do Centro de Estudos Geográficos, Fac. de Letras, Cidade Universitária, 1699 Lisboa Codex. Tel: (351-1) 79402 18; fax: (351-1) 793 8690

2 As referências completas das obras mencionadas podem encontrar-se na tábua bibliográfica incluída neste número da Finisterra. 
sobre as opções teóricas e «epistemológicas» que, várias vezes dispensável, se tornou recentemente habitual em muitas teses.

Outro aspecto me chamou particularmente a atenção na tese de Suzanne Daveau - por gosto pessoal pela matéria e pela importância de que se reveste para a compreensão das questões tratadas: refiro-me a toda a parte da investigação histórica, conduzida com grande rigor e integrada com perfeito equilíbrio no âmbito geográfico da obra. Noutro lugar do presente número da Finisterra, José Mattoso refere-se, de forma penetrante e com a competência que lhe é reconhecida, à relevância assumida pelas relações entre a Geografia e a História no conjunto dos trabalhos de Suzanne Daveau.

Compreende-se bem que a sua atracção pela história tenha sido acentuada num país como Portugal, onde ela se mostra tão influente nas formas da organização do espaço, pela inércia, até tarde sentida, das estruturas económico-sociais; e onde está ligada a fecundos contactos de civilização, cujos traços perduram nos mais variados recantos do Mundo. Um dos seus primeiros trabalhos de investigação em geografia humana no nosso país teve como tema a organização do povoamento na serra da Estrela (1970), com base na comparação dos dados do numeramento de 1527 e do censo de 1960. Note-se que este trabalho aparece na sequência de investigações sobre aquele acidente de relevo: e o mesmo haveria de acontecer mais tarde, por exemplo em relação à Lousã (1988), com análises de geografia humana, na sequência de pesquisas fundamentais de geomorfologia.

No entanto, e a par da persistente solicitação pelas matérias de geografia histórica (sem falar das de geografia física), a própria geografia humana, num sentido mais lato, haveria de constituir tema de vários trabalhos. Aliás, nos anos 60, quando tinha ensinado e investigado na África, isso já acontecera: num caso e no outro, com clara preferência pelas formas tradicionais da ocupação humana, ligadas sobretudo ao espaço rural.

$\mathrm{E}$, através da ponderação conjunta dos elementos físicos e humanos do ambiente geográfico, Suzanne Daveau desloca-se, de forma mais ou menos assumida, para o domínio da geografia regional, que não terá cultivado muito (para além das obras de conjunto sobre a geografia de Portugal, adiante aludidas), mas em relação ao qual deixou ideias bem claras. Num caderno policopiado de apoio ao ensino de Geografia Regional (1978), necessariamente esquemático mas rico na exposição dos conceitos e escolha dos textos propostos para reflexão, assinala que o estudo daquela disciplina «pode ser completo (monografia regional) e tender a pôr em realce, tanto a 'personalidade' ou individualidade do espaço estudado (não existem dois iguais), como a reconhecer o seu 'tipo' taxonómico, com vista ao estabelecimento de uma Geografia geral dos espaços regionais» (p. 2). No pensamento de Suzanne Daveau, um estudo assim elaborado pressupõe o tratamento equilibrado das matérias de geografia física e de geografia humana, sem que haja o predomínio sensível desta última, que tinha sido preconizado por influentes geógrafos portugueses, designadamente por Orlando Ribeiro. Concluindo o seu raciocínio, acrescenta a autora que «o estudo regional pode também ser sectorial (o clima, a evolução da população, as relações económicas, ... dentro de um certo espaço), tendo qualquer fenómeno geográfico, para ser 
plenamente entendido, de ser encarado tanto nas suas relações com os outros elementos do complexo local, como no seu contexto regional e mundial. Desde que o estudo regional abranja aspectos humanos, observa-se que os tipos de organização do espaço e de relações entre o homem e o ambiente (ecologia) são reflexos das características socio-económicas (ou civilizações) dos grupos humanos presentes. Daqui a dificuldade em adaptar esquemas (ou modelos) regionais sólidos num certo contexto humano a sociedades diferentes» (p. 2)

$\mathrm{O}$ estudo sistemático dos vários fenómenos geográficos em relação a determinado espaço foi concretizado com sucesso por Suzanne Daveau no contexto de Portugal. Ao retomar o velho projecto de Orlando Ribeiro, perseguido com pertinácia mas sucessivamente adiado, de elaborar uma geografia desenvolvida do nosso país, Suzanne Daveau foi levada a organizar uma monumental obra em 4 volumes, na qual reuniu, segundo uma sistematização coerente e exaustiva, um trabalho daquele geógrafo, sucinto em confronto com o que ambicionava e conhecido apenas em versão castelhana (1955), e um outro do alemão Hermann Lautensach, que só havia sido publicado na sua língua, mais desenvolvido, mas bem anterior (1932). Suzanne Daveau juntou-lhes comentários e actualizações que, além de constituírem parte substancial da obra, mostram a sua abertura (de resto, já revelada anteriormente) para o estudo de aspectos «actuais» da geografia humana, relacionados com as transformações recentes que se vão operando em ritmo acelerado e recobrem temas de investigação por vezes especializados.

Mais tarde, a autora haveria de elaborar a sua própria geografia de Portugal (Portugal Geográfico, 1995), sob a forma de uma síntese condensada, de concepção original, onde se entrelaçam os mais variados assuntos, sempre com o cuidado de enquadrar o país em contextos de dimensão suficientemente ampla, segundo preocupações metodológicas acima aludidas.

Em números recentes desta revista dei notícia das obras que acabo de citar. Através delas colhe-se bem a imagem do contributo de Suzanne Daveau para uma geografia humana e regional; mas não só através delas: toda a sua actividade, o conjunto dos seus numerosos trabalhos dão conta duma notável vocação de geógrafa, a que muito fica a dever o nosso país e, em geral, a ciência a que com tanta dedicação se consagrou. 